\title{
PENINGKATAN ENZIM TRANSAMINASE PADA KUSTA
}

\author{
Felix Hartanto, Prima Kartika Esti
}

KMF Kulit dan Kelamin RS Kusta Dr. Sitanala, Tangerang

\begin{abstract}
ABSTRAK
Penyakit kusta adalah penyakit infeksi kronik yang mengenai kulit dan sistem saraf perifer dan disebabkan oleh Mycobacterium leprae, yaitu bakteri tahan asam dan bersifat intraseluler obligat. Seiring berkembangnya ilmu kedokteran saat ini, kusta dianggap sebagai sebuah penyakit sistemik dan organ hepar menjadi salah satu yang terlibat dalam proses patologis penyakit kusta.

Komplikasi gangguan fungsi hepar akibat penyakit kusta selama ini kurang mendapat sorotan, padahal gangguan fungsi hepar secara teoritis hampir pasti menyertai setiap penderita kusta, terutama pada saat timbul reaksi ENL. Pada kenyataannya, gangguan fungsi hepar yang ditandai dengan peningkatan enzim transaminase dapat terjadi akibat berbagai penyebab, yaitu efek samping obat yang bersifat hepatotoksik, koinfeksi kusta dengan virus hepatitis, pembentukan granuloma di hepar dari proses patologis penyakit kusta, ataupun akibat dari proses imunologik reaksi ENL yang melibatkan organ hepar.

Tulisan ini mencoba untuk mengupas lebih dalam tetang peningkatan enzim transaminase yang terjadi pada penyakit kusta. Pengetahuan tentang hal ini diharapkan dapat memberi manfaat dalam penegakan diagnosis dan mendukung penanganan pasien secara menyeluruh.
\end{abstract}

Kata kunci: kusta, enzim transaminase, eritema nodosum leprosum, drug induced liver injury, granuloma

\section{ELEVATION OF TRANSAMINASE ENZYME LEVELS IN LEPROSY}

\begin{abstract}
Leprosy is a chronic infection that affects the skin and peripheral nervous system, caused by Mycobacterium leprae, which is an acid fast bacilli and intracellular obligate pathogen. As the development of medical science today, leprosy is regarded as a systemic disease and liver become one of the organs involved in the pathological process of leprosy.

Complication of liver function impairment caused by leprosy has been getting less attention, whereas theoretically liver function impairment almost certainly accompanies leprosy patients, especially when the ENL reaction arises. In fact, hepatic involvement characterized by increased transaminase enzymes may result from various causes, i.e. hepatotoxic drugs, viral hepatitiscoinfection, hepatic granuloma formation in the liver from pathological process of leprosy itself, or as a result of the immunological process that accompanies ENL reaction.

This paper attempts to review the increase of transaminase enzymes that occurs in leprosy. Therefore this knowledge is expected to provide benefits in diagnosis and support morecomprehensivepatient care.
\end{abstract}

Keywords: leprosy, transaminase enzymes, erythema nodosum leprosum, drug induced liver injury, hepatic granuloma

\section{Korespondensi:}

Jalan Dr. Sitanala Nomor 99, Tangerang, 15001

Telp/Fax : (021) 5523059 / (021) 5523111

Email: felixhartanto707@gmail.com; primakartika@yahoo.com 


\section{PENDAHULUAN}

Morbus Hansen (MH) atau yang biasa kita kenal dengan sebutan kusta adalah penyakit infeksi kronik yang menyerang kulit dan sistem saraf perifer. Penyakit tersebut disebabkan oleh Mycobacterium leprae, yaitu bakteri yang bersifat tahan asam dan intraseluler obligat. ${ }^{1}$ Selain menyerang kulit dan sistem saraf perifer, kusta juga dapat menyerang organ internal, terutama organ hepar. Gangguan fungsi dapat terjadi pada varian kusta tipe tuberkuloid sampai lepromatosa, tetapi akan lebih jelas terlihat pada saat terjadi reaksi kusta, terutama reaksi kusta tipe II (Eritema Nodosum Leprosum/ENL). ${ }^{2}$

Menurut data WHO tahun 2015, terdapat 210.758 kasus kusta baru di seluruh dunia dan Indonesia menduduki peringkat ketiga terbanyak dengan jumlah rerata 17.700 kasus baru per tahun. ${ }^{3}$ Walaupun jumlah kasus kusta baru di dunia dan di Indonesia sudah dapat ditekan jauh sejak pertengahan tahun 1980, pada tahun 2016 sebanyak dua belas provinsi di Indonesia masih termasuk high burden. ${ }^{4}$ Kemajuan pengobatan dengan MDT (Multi Drug Treatment) berperan penting dalam proses eradikasi kusta secara global, termasuk juga di Indonesia. ${ }^{3,5}$

Kulit dan saraf perifer merupakan aspek klinis penyakit kusta yang sering dibicarakan. Komplikasi gangguan fungsi hepar selama ini kurang mendapat sorotan, padahal gangguan fungsi hepar secara teoritis hampir pasti menyertai setiap penderita kusta, terutama pada saat timbul reaksi ENL. ${ }^{6}$

Selama ini, mayoritas klinisi beranggapan bahwa gangguan fungsi hepar yang ditemukan pada pasien kusta terjadi akibat drug induced liver injury (DILI). Pada kenyataannya, gangguan fungsi hepar yang ditandai dengan peningkatan enzim transaminase dapat terjadi akibat dari berbagai penyebab, yaitu efek samping obat yang bersifat hepatotoksik, koinfeksi kusta dengan virus hepatitis, pembentukan granuloma di hepar dari proses patologis penyakit kusta, ataupun akibat proses imunologik reaksi ENL yang melibatkan organ hepar. ${ }^{7,8}$

\section{ENZIM TRANSAMINASE}

Enzim transaminase adalah kelompok enzim yang berperan dalam proses katalisis reaksi transaminase. Enzim tersebut mengkatalisis transfer gugus amino (-NH2) dari asam amino ke senyawa karbonil, umumnya asam $\alpha$-keto (asam dengan rumus umum $\mathrm{RCOCOOH}$ ). Organ hepar manusia mempunyai enzim transaminase spesifik untuk melakukan transfer gugus amino dari asam glutamat ke asam $\alpha$-keto yang sesuai dengan sebagian besar asam amino lainnya., ${ }^{9,10}$

Terdapat dua jenis enzim transaminase yang dikenal luas, yaitu: 1) aspartate aminotransferase (AST) atau serum glutamic oxaloacetic transaminase (SGOT), dan 2) alanine aminotransferase (ALT) atau serum glutamic pyruvic transaminase (SGPT). Kedua enzim tersebut banyak ditemukan dalam sitosol dan mitokondria sel hepatosit, sehingga apabila terdapat kerusakan hepatoselular yang diikuti oleh kerusakan membran plasma, maka enzim transaminase yang terdapat di intrasel dapat bocor dan ditemukan di dalam serum darah. ${ }^{10}$ Selain hepar, organ lain misalnya jantung, otot rangka, ginjal, otak dan pakreas juga mengandung kedua enzim transaminase tetapi dalam jumlah yang lebih sedikit., ${ }^{9} 10$

Gambar (1) di bawah ini menjelaskan tentang reaksi pembentukan enzim transaminase yang terbanyak ditemukan dalam jaringan tubuh manusia. Kedua enzim ini akan dilepaskan ke dalam serum apabila terdapat kerusakan pada jaringan yang memproduksinya.

1. "Glutamic - oxaloacetic transaminase"

Aspartate $+\alpha$-keto glutarate $\leftrightarrow$ glutamate + oxaloacetate

2. "Glutamic - pyruvic transaminase"

Alanine $+\alpha$-keto glutarate $\leftrightarrow$ glutamate + pyruvate

Gambar 1. Enzim transaminase yang ada dalam jaringan tubuh manusia

\section{PATOGENESIS}

Bakteri M.leprae masuk ke dalam tubuh manusia sampai saat ini masih diyakini melalui 2 jalur utama, yaitu kulit dan saluran pernapasan atas. ${ }^{111}$ Target utama bakteri adalah sel Schwann yang terdapat di saraf perifer. Bakteri M.leprae mempunyai glikoprotein PGL-1 (phenolic glycolipid-1) pada permukaannya yang dapat berikatan dengan protein laminin yang terdapat pada sel Schwann. M.leprae melekat pada sel Schwann menyebabkan terjadinya demielinisasi saraf serta hilangnya konduksi pada akson saraf perifer. ${ }^{11}$

Seperti yang kita tahu bahwa di lapisan dermis dan epidermis kulit manusia terdapat makrofag yang berperan sebagai "skin barrier" terhadap patogen yang masuk. Sel makrofag inilah yang berperan awal dalam melawan Mycobacterium yang masuk ke tubuh.Proses fagositosis bakteri M.leprae oleh makrofag diperantarai oleh reseptor komplemen CR1 (CD35), CR3 (CD11b/CD18), dan CR4 (CD11c/CD18) dan diregulasi oleh enzim protein kinase. Hasil dari proses fagositosis ini adalah terbentuknya granuloma. ${ }^{11}$

Pada temuan histopatologi lesi kulit pasien kusta tipe tuberkuloid, dapat ditemukan infiltrat inflamasi yang terdiri dari granuloma berisi basil bakteri tahan asam dan makrofag, sel epitel, giant cells, dan juga banyak terdapat sel TCD4 ${ }^{+}$. Jumlah bakteri pada lesi tuberkuloid dapat sangat rendah sampai tidak ditemukan adanya bakteri. Karakteristik histopatologis kusta tipe lepromatosa, yaitu tidak adanya pembentukan granuloma, memiliki jumlah sel $\mathrm{T} \mathrm{CD}^{+}$yang lebih besar, serta jumlah basil bakteri yang sangat tinggi. Oleh karena itu, kusta tipe lepromatosa diasosiasikan dengan sistem imun seluler penderita yang lebih rendah. ${ }^{1,11}$

Beberapa faktor yang berpengaruh dapat menyebabkan peningkatan enzim transaminase pada penyakit kusta. Tidak hanya terbatas pada DILI saja, tetapi juga terdapat granuloma hepatikum yang menyertai penyakit kusta, reaksi imun yang menyertai reaksi ENL, dan koinfeksi dengan penyakit hepatitis. Faktor-faktor tersebut di atas dapat dilihat dalam bentuk diagram pada gambar 2 . 


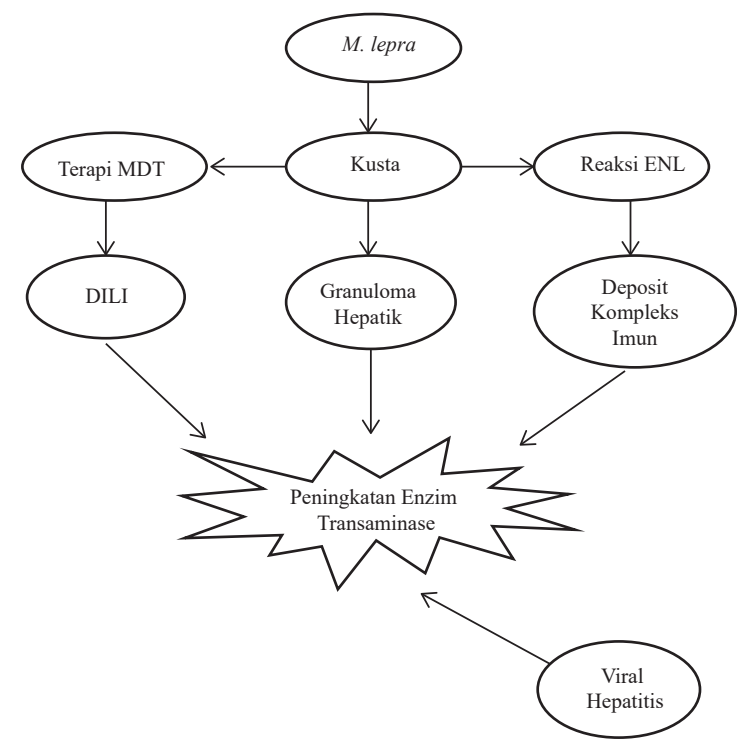

Gambar 2. Patogenesis peningkatan enzim transaminase pada kusta

Seiring berkembangnya ilmu kedokteran saat ini, kusta dianggap sebagai penyakit sistemik dan organ hepar menjadi salah satu yang terlibat dalam proses patologis penyakit kusta. Keterlibatan hepar dapat terjadi pada semua tipe kusta, terutama pada kusta tipe LL. Proses keterlibatan organ hepar pada kusta dapat berjalan secara asimptomatik dengan disertai atau tanpa disertai peningkatan petanda (enzim transaminase). ${ }^{7}$

Temuan histopatologis yang terjadi di hepar dapat dibagi menjadi dua macam, yaitu: 1) lesi granuloma di parenkim hepar; dan 2) lesi nonspesifik. Lesi nonspesifik pada hepar dapat dibagi menjadi 3 jenis, yaitu: 1) nekrosis fokal hepatosit, 2) hiperplasia sel Kupffer, dan 3) triaditis portal yang meliputi infiltrasi difus dari limfosit, sel mononuklear, dan neutrofil pada area di sekitar portal hepatis. Pada penderita tidak selalu ditemukan seluruh lesi tersebut, tetapi studi beberapa literatur menunjukkan bahwa pada kasus kusta hampir selalu diikuti oleh salah satu lesi hepatik seperti yang disebutkan di atas. ${ }^{12}$

Granuloma terjadi ketika respons kekebalan humoral atau seluler gagal untuk menghilangkan benda asing yang masuk ke tubuh. Hal tersebut merupakan respons dari hipersensitivitas tipe IV (delayed type hypersensitivity), yang mencoba untuk mengisolasi dan menetralisir bahan patogen yang sulit untuk dimusnahkan. Pembentukan granuloma disebabkan oleh reaksi inflamasi kronis dengan adanya sel epiteloid atau sel multinuklear raksasa yang dikelilingi oleh limfosit, monosit, dan sel plasma. Sel epiteloid (atau sering disebut sel epiteloid histiosit) merupakan jaringan modifikasi dari monosit, makrofag, dan histiosit dari darah. ${ }^{13}$

Patofisiologi terbentuknya granuloma hepatik pada kusta dimulai dari fagositosis bahan patogen oleh makrofag yang ada di kulit. Makrofag kemudian memproses patogen tersebut menjadi antigen peptida sederhana, yang kemudian akan dipresentasikan ke limfosit-T. Proses tersebut akan merangsang limfosit-T menjadi aktif dan menghasilkan berbagai sitokin yang menyebabkan pula aktivasi sel $\mathrm{T}$ lainnya, serta akan mengkonversi histiosit dan makrofag menjadi sel epiteloid histiosit. Sel epiteloid histiosit inilah yang akan beragregasi menjadi granuloma dan terakumulasi di porta hepatis di hepar, seperti yang terlihat pada gambar (3). ${ }^{13,14}$
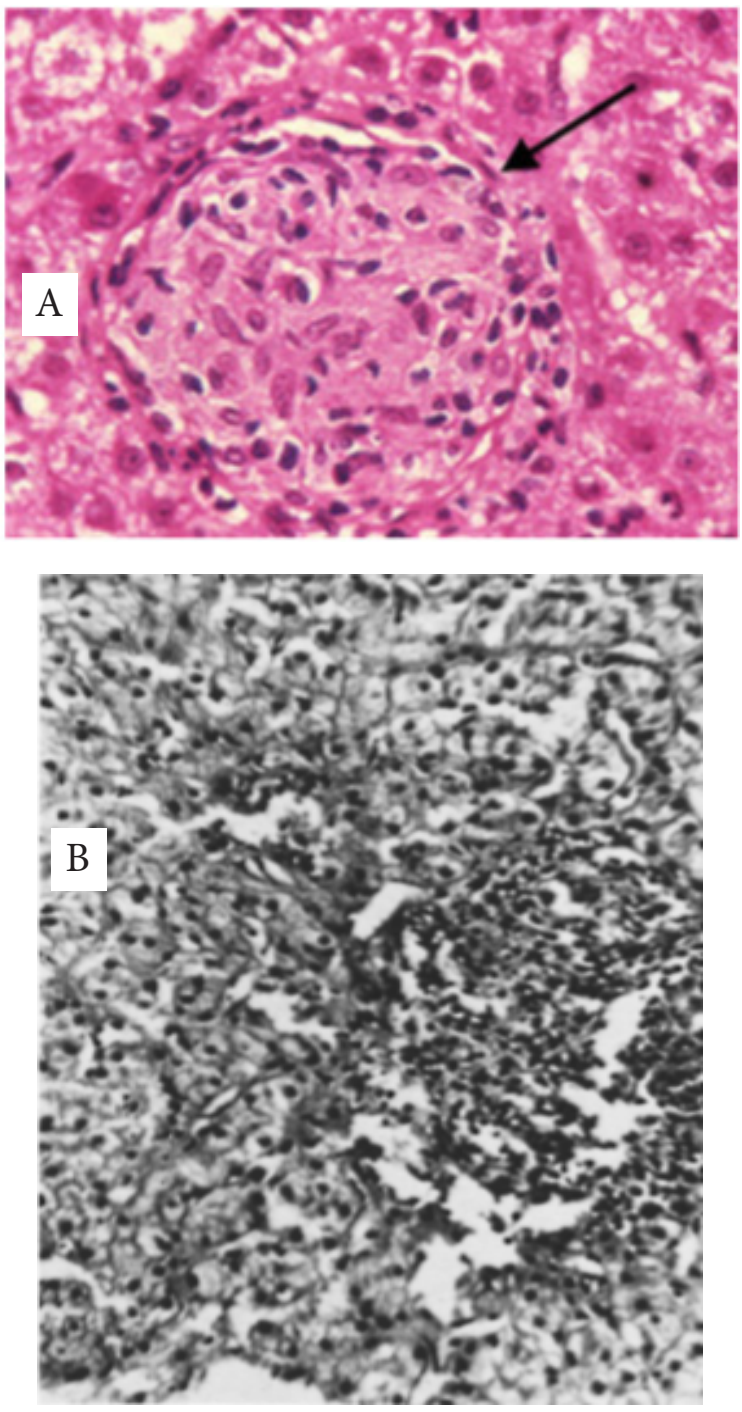

Gambar 3. (A) Granuloma sel epiteloid di hepar (pewarnaan HE, pembesaran 400x $)^{13}$; (B) Granuloma hepatik pada parenkim hepar yang terbentuk dari kumpulan histiosit, leukosit, dan sel epiteloid (pewarnaan HE, pembesaran $240 x)^{12}$

Berbeda dengan di kulit, pembentukan granuloma hepatik pada kusta meningkat jumlahnya dari tipe polar tuberkuloid ke polar lepromatosa. Angka kejadian granuloma hepatik adalah sebesar $21 \%$ pada kusta tipe tuberkuloid (TT), 47\% pada kusta tipe borderline tuberculoid (BT), dan $62 \%$ pada kusta tipe lepromatosa (LL). Hal tersebut menunjukkan bahwa korelasi antara indeks bakteri yang semakin tinggi akan meningkatkan prevalensi terjadinya granuloma hepatik. ${ }^{13,15}$ Yang membedakan granuloma hepatik pada tipe LL (lepromatous granulomata) adalah ditemukannya sejumlah bakteri tahan asam di dalam lobulus, sedangkan granuloma pada tipe TT (tuberculoid 
granulomata) berbentuk diskret dan sangat jarang ditemukan bakteri tahan asam di dalamnya. ${ }^{13}$

\section{Reaksi ENL}

Reaksi kusta disebabkan oleh respons imun terhadap antigen pada $M$. leprae (PGL-1) yang memicu terbentuknya proses kaskade imunitas humoral dan seluler pada tubuh penderita, yang dapat timbul sebelum, selama, atau setelah pengobatan MDT selesai. ${ }^{6}{ }^{616}$ Reaksi kusta tipe I (reaksi reversal) terjadi pada kurang lebih 30\% penderita kusta dan lebih sering dijumpai pada kasus kusta tipe borderline, walaupun tidak menutup kemungkinan untuk timbul pada semua spektrum kusta. ${ }^{6}$ Reaksi reversal biasanya berupa lesi kulit yang semakin membesar, makin eritematosa, kadang dapat disertai neuritis dan gangguan fungsi saraf. ${ }^{1,6}$ Reaksi reversal tersebut diperantarai oleh reaksi hipersesitivitas tipe IV (delayed type hypersensitivity). ${ }^{17}$

Reaksi kusta tipe II (reaksi ENL), lebih banyak timbul pada kusta tipe borderline lepromatosa (BL) dan LL., ${ }^{1,6,17}$ Prevalensi kejadian reaksi ENL terjadi pada $30-50 \%$ penderita kusta. ${ }^{6}$ Reaksi ENL tidak hanya menyebabkan lesi pada kulit berupa nodus eritematosa, tetapi juga dapat menyebabkan kerusakan pada saraf, mata, dan juga organ sistemik, terutama hepar. ${ }^{6}$ Reaksi ENL diperantarai oleh reaksi hipersentivitas tipe III, yang melibatkan sistem imun komplemen. ${ }^{17}$ Hal ini yang menyebabkan gejala sistemik lebih sering timbul pada reaksi ENL dibandingkan reaksi reversal. Gejala sistemik yang sering muncul menyertai reaksi ENL adalah demam, neuritis, artritis, dan peningkatan enzim transaminase hepar. ${ }^{6,16}$

Reaksi ENL berhubungan erat dengan perubahan aktivitas sitokin inflamasi di dalam tubuh penderita kusta. Pada saat terjadi reaksi ENL, terjadi peningkatan TNF- $\alpha$, INF- $\gamma$, TGF- $\beta$, IL-10, IL-6, IL-8, dan IL-1B dalam serum, yang berhubungan dengan gejala akut yang timbul pada pasien. Kenaikan kadar TGF- $\beta$ tersebut juga menyebabkan penekanan pada imunitas seluler penderita. Seiring dengan pemberian terapi kortikosteroid pada reaksi ENL, maka kadar sitokin inflamasi tersebut akan mulai turun. ${ }^{18}$

Peningkatan enzim transaminase (SGOT dan SGPT) pada kasus kusta mayoritas terjadi pada kusta tipe LL, terutama pada saat terjadinya reaksi ENL. Hal tersebut berhubungan dengan terbentuknya kompleks imun yang melibatkan komplemen dan terdeposit di sel hepar. ${ }^{7}$ Pada penderita yang mengalami reaksi ENL, terdapat persamaan temuan histopatologis di hepar dan kulit. ${ }^{2}$ Biopsi hepar pada pasien kusta dengan reaksi ENL menunjukkan gambaran lesi eksudatif, granuloma epiteloid dan tuberkuloid, juga granuloma sel busa (foam-cell granulomas), seperti yang ditunjukkan pada gambar (4). Infiltrasi neutrofil ke dalam granuloma sel busa juga terlihat pada beberapa kasus kusta tipe LL dengan reaksi ENL. ${ }^{7,18}$

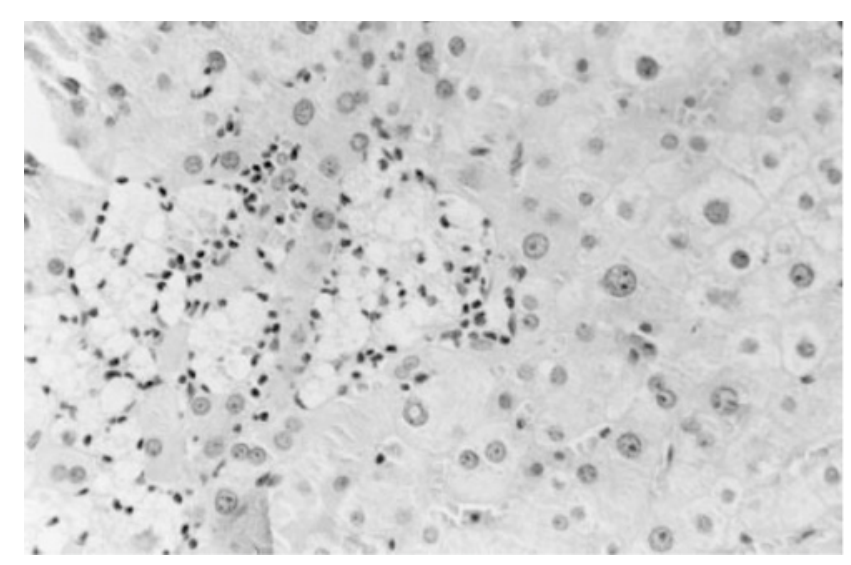

Gambar 4. Deposit fokal pada hepar oleh sel-sel inflamasi (terutama limfosit) pada kasus kusta tipe LL dengan reaksi ENL. Sel hepatosit juga menunjukkan degenerasi vacuolar, serta terdapat deposit sel busa pada portal (pewarnaan HE, pembesaran 400x). ${ }^{7}$

Hingga saat ini berdasarkan literatur yang ada, keterlibatan organ hepar dalam reaksi ENL tidak selalu diikuti oleh peningkatan enzim transaminase dalam serum, atau mungkin hanya terjadi peningkatan ringan dari enzim transaminase. Apabila terjadi peningkatan enzim transaminase, biasanya enzim tersebut akan meningkat 2-3x kadar normal, dan peningkatan dalam kadar tersebut sudah dikatakan cukup tinggi untuk reaksi ENL. Enzim transaminase yang meningkat dapat kedua enzim, atau salah satu saja. ${ }^{7}$

\section{DIAGNOSIS BANDING}

Mekanisme keterlibatan organ hepar pada kusta dapat terjadi akibat beberapa hal sebagai berikut: 1) infiltrasi granuloma pada hepar, 2) kerusakan yang diperantarai oleh reaksi kompleks imun pada reaksi ENL, 3) Drug induced liver injury (DILI), dan 4) koinfeksi virus hepatitis B atau C. ${ }^{2}$ Dalam menentukan gangguan fungsi hepar yang terjadi pada pasien, klinisi harus bijak dalam menyingkirkan semua diagnosis banding tersebut terlebih dahulu sebelum menentukan penyebab dan tata laksana yang akan diberikan.

DILI akibat MDT diakibatkan oleh 2 obat utama, yaitu dapson dan rifampisin., ${ }^{1,2}$ Penelitian di beberapa center di Amerika Serikat tahun 2010, menunjukkan angka kejadian DILI pada pasien yang mengonsumsi dapson berkisar antara $4-5 \% .{ }^{19}$ Sedangkan angka kejadian DILI pada pasien yang mengonsumsi rifampisin secara umum dilaporkan sangat rendah, yaitu berkisar antara $0-1 \% .^{20,21}$ Efek samping hepatotoksik terhadap rifampisin akan meningkat prevalensinya yang dipengaruhi oleh faktor usia. ${ }^{22}$ DILI biasa terjadi pada 4-6 minggu setelah mulainya terapi MDT. Pada pasien yang mendapat terapi kortikosteroid oleh karena reaksi kusta ataupun neuritis berbarengan dengan mulainya MDT, awitan timbulnya DILI dapat lebih dari 6 minggu setelah MDT dimulai. ${ }^{2}$ DILI akibat MDT dapat timbul pada semua tipe kusta. Oleh karena itu, di sini penting penggalian anamnesis yang teliti sebelum menegakkan diagnosis DILI. 
Pemeriksaan fungsi hepar serial secara berkala sejak dimulainya MDT juga penting dalam pemantauan efek samping akibat MDT. ${ }^{2}$ Apabila pada pemeriksaan fungsi hepar serial didapati terjadinya peningkatan enzim transaminase yang gradual dan progresif, maka hal tersebut dapat menjadi tanda bahwa telah terjadi DILI pada pasien tersebut. ${ }^{7}$ Seperti halnya pada kasus tuberkulosis, apabila didapati peningkatan enzim transaminase sebelum diberikan pengobatan anti tuberkulosis (OAT), maka OAT dapat tetap diberikan. ${ }^{22}$ Begitu pula pada kasus kusta, MDT dapat tetap diberikan meskipun ditemukan peningkatan enzim transaminase sebelum pengobatan, dengan pertimbangan peningkatan tersebut diakibatkan oleh faktor penyebab lain dan penyakit kusta tetap harus diobati, disertai evaluasi fungsi hepar secara berkala. Penghentian sementara MDT dapat dipertimbangkan apabila terjadi peningkatan enzim transaminase yang sangat tinggi sambil dilakukan evaluasi selanjutnya. ${ }^{2,7}$ Sejauh ini, belum ada literatur yang menyatakan berapa kadar peningkatan transaminase yang menjadi batas atas untuk dihentikannya MDT. Hanya saja diperlukan pula gabungan penilaian secara klinis sehingga tidak hanya berpatokan pada hasil laboratorium semata.

Eliminasi kemungkinan koinfeksi hepatitis viral pada pasien dengan peningkatan enzim transaminase juga penting, sebelum klinisi menentukan penyebab dari gangguan fungsi hepar yang terjadi. Penelitian di Brazil pada tahun 2012 menunjukkan angka koinfeksi hepatitis B atau C sebesar 6-7\% dari keseluruhan pasien kusta. ${ }^{8}$ Dalam hal ini, pemeriksaan fisik dan laboratorium penting untuk menentukan diagnosis koinfeksi hepatitis viral pada pasien kusta. Pemeriksaan HbsAg dan anti-HCV penting untuk menyingkirkan kemungkinan diagnosis hepatitis viral apabila didapatkan pasien dengan peningkatan enzim transaminase. ${ }^{2,8}$ Apabila memang didapati temuan hepatitis viral pada pasien, maka penanganan bersama dengan bagian penyakit dalam menjadi penting.

\section{PENEGAKAN DIAGNOSIS}

Setelah menyingkirkan dua kemungkinan penyebab gangguan fungsi hepar yang lain, klinisi dapat mengarahkan penyebab gangguan fungsi hepar akibat infiltrasi granuloma hepatik atau kompleks imun yang terdeposit di hepar, terutama pada kasus reaksi ENL. Kejadian gangguan fungsi hepar akan meningkat apabila ENL sudah terjadi berulang. ${ }^{2}$

Pada pemeriksaan fisik, hepatomegali ringan juga dapat ditemukan pada pasien akibat adanya infiltrasi granuloma hepatik yang menyebabkan gangguan fungsi hepar., ${ }^{6,18}$ Pemeriksaan biopsi hepar menjadi baku emas dalam melihat apakah terjadi proses patologis di hepar, berupa granuloma hepatik atau deposit kompleks imun lainnya. ${ }^{12,18}$ Terlebih apabila didukung peningkatan enzim transaminase yang bersifat ringan (tidak melebihi $3 \mathrm{x}$ kadar normal), maka klinisi dapat lebih yakin bahwa hal tersebut disebabkan oleh granuloma hepatik yang menyertai penyakit kusta.

\section{TATA LAKSANA}

Kortikosteroid dipertimbangkan sebagai pilihan utama dalam kasus gangguan fungsi hepar akibat granuloma hepatik dan deposit kompleks imun pada reaksi ENL. Pemberian kortikosteroid dosis $1 \mathrm{mg} / \mathrm{kgBB} /$ hari akan memberikan respons terapi yang baik, ditunjukkan dengan penurunan kadar enzim transaminase serum dalam beberapa hari setelah pemberian.?

Pada sejumlah kasus tertentu dapat dijumpai peningkatan enzim transaminase yang sangat tinggi, menandakan bahwa kerusakan hepatosit yang terjadi sangat luas. ${ }^{7}$ Pada kondisi sepert ini, pemberian kortikosterid dosis standard $1 \mathrm{mg} / \mathrm{kgBB} /$ hari tidak akan memberikan hasil yang optimal, sehingga dapat dipertimbangkan pemberian dosis kortikosteroid yang lebih tinggi. ${ }^{2,7}$

Penggunaan thalidomid sebagai monoterapi ataupun terapi kombinasi dengan kortikosteroid pada kasus reaksi ENL tidak dianjurkan apabila didapati adanya peningkatan enzim transaminase pada pasien. Thalidomid lebih dikenal akan efek samping teratogeniknya, tetapi beberapa laporan kasus melaporkan adanya DILI yang disebabkan oleh thalidomid, walaupun hal tersebut merupakan kasus yang sangat jarang. Efek samping DILI oleh thalidomid juga dilaporkan akan meningkat apabila sebelumnya pasien memiliki riwayat penyakit hati kronik..$^{22,23}$

\section{SIMPULAN}

Peningkatan enzim transaminase yang dapat menyertai kasus kusta tidak hanya disebabkan oleh DILI saja seperti anggapan selama ini. Dengan berkembangnya ilmu kedokteran telah terbukti bahwa pada penyakit kusta, terutama saat reaksi ENL, terdapat pula proses patologis di hepar, yang dapat menyebabkan peningkatan enzim transaminase. Kejelian dan kemantapan dalam penegakan diagnosis oleh klinisi dibutuhkan dalam menghadapi kondisi ini. Penetapan pengecekan HbsAg dan anti-HCV pada pasien kusta dengan peningkatan enzim transaminase dapat menjadi pertimbangan untuk dijadikan prosedur standard di rumah sakit.

\section{PENUTUP}

Telah diurai tentang penyebab dan patofisiologi keterlibatan organ hepar pada penyakit kusta. Pengetahuan ini diharapkan dapat meningkatkan pelayanan dokter dalam menangani pasien kusta secara lebih holistik di masa depan. 


\section{DAFTAR PUSTAKA}

1. Wisnu IM, Sjamsoe-Daili ES, Menaldi SL. Kusta. Dalam:Menaldi SL, Bramono K, Indriatmi W, penyunting. Ilmu penyakit kulit dan kelamin. Edisi ke-7. Jakarta: Balai Penerbit FKUI; 2017. h. 87-102.

2. Mendiratta V, Malik M, Gurtoo A, Chander R. Fulminant hepatic failure in a 15 year old boy with borderline lepromatous leprosy and Type 2 reaction. Lepr Rev. 2014; 85: 54-7.

3. World Health Organization. Global leprosy update, 2015: time for action, accountability and inclusion. Weekly Epid Rec. 2016; 91: 405-20.

4. Data dan informasi profil kesehatan Indonesia 2016. Pusat Data dan Informasi Kementerian Kesehatan RI 2017.

5. Rodrigues LC, Lockwood DN. Leprosy now: epidemiology, progress, challenges, and research gaps. Lancet Infect Dis. 2011; 11: 464-70

6. Leon KE, Salinas JL, McDonald RW, Sheth AN, Fairley JK. Complex type 2 reactions in three patients with hansen's disease from a southern united states clinic. Am J Trop Med Hyg. 2015; 93: 1082-6.

7. Ferrari TCA, Araujo MG, Ribeiro MMF. Hepatic involvement in lepromatous leprosy. Lepr Rev. 2002; 73: 72-5.

8. Motta ACF, Pereira KJ, Tarquinio DC, Vieira MB, Miyake K, Foss NT. Leprosy reactions: coinfections as a possible risk factor. Clinics. 2012; 67: 1145-8.

9. Karmen A, Wroblewski F, Ladue JS. Transaminase activity in human blood. J Clin Invest. 1995; 34: 126-33.

10. Amacher DE. Serum transaminase elevations as indicators of hepatic injury following the administration of drugs. Regul Toxicol and Pharmacol. 1998; 27: 119-30.

11. Bhat RM, Prakash C. Leprosy: an overview of pathophysiology. Interdisciplinary Perspectives on Infectious Disease. 2012. [Disitasi 6 Januari 2018]. Tersedia di: https://www.hindawi.com/ journals/ipid/2012/181089/.

12. Mittal MM, Maheshwari HB, Saha K, Sharma R. Hepatic lesions in asymptomatic children of leprosy patients. Int J Lepr. 1997; 46: 42-6.
13. Coash M, Forouhar F, Wu CH, Wu GY. Granulomatous liver diseases: a review. J Formos Med Assoc. 2012; 111: 3-13.

14. Heyworth PG, Cross AR, Curnutte JT. Chronic granulomatous disease. Curr Opin Immunol. 2003; 15: 578-84.

15. Karat ABA, Job CK, Rao PSS. Liver in leprosy: histological and biochemical findings. Br Med J. 1971; 1: 307-10.

16. Negera E, Bobosha K, Walker SL, Endale B, Howe R, Aseffa A, Dockrell HM, Lockwood DN. New Insight into the Pathogenesis of Erythema Nodosum Leprosum: The Role of Activated Memory T-Cells. Front. Immunol. 2017; 8: 1149-63.

17. Lee DJ, Rea TH, Modlin RL. Leprosy. Dalam: Goldsmith LA, Katz SI, Gilchrest BA, Paller AS, Leffell DJ, Wolff K, penyunting. Fitzpatrick's dermatology in general medicine. Edisi ke-8. New York: McGraw-Hill; 2012. h. 2253-63.

18. Patnaik JK, Saha PK, Satpathy SK, Das BS, Bose TK. Hepatic morphology in reactional states of leprosy. Int J Lepr. 1989; 57: 499-505.

19. Reuben A, Koch DG, Lee WM. Drug-induced acute liver failure: results of a U.S. multicenter, prospective study. Hepatology. 2010; 52: 2065-76.

20. Yee D, Valiquette C, Pelletier M, Parisien I, Rocher I, Menzies D. Incidence of serious side effects from first-line antituberculosis drugs among patients treated for active tuberculosis. Am J Respir Crit Care Med. 2003; 167: 1472-7.

21. Crevel RV, Alisjahbana B, Lange WCM, Borst F, Danusantoso H, Meer JWM, Burger D, Nelwan RHH. Low plasma concentration of rifampicin in tuberculosis patients in Indonesia. Int J Tuberc Lung Dis. 2002; 6(6): 497-502.

22. Prihatni D, Parwati I, Sjahid I, Rita C. Efek hepatotoksik anti tuberkulosis terhadap kadar aspartate aminotransferase dan alanine aminotransferase serum penderita tuberkulosis paru. Id J Clin Pathol Med Lab. 2005; 12(5): 1-5.

23. Hanje AJ, Shamp JL, Thomas FB, Meis GM. Thalidomide-induced severe hepatotoxicity. Pharmacotherapy. 2006;26(7):1018-22.

24. Fowler R, Imrie K. Thalidomide-associated hepatitis: a case report. Am J Hematol. 2001;66:300-2. 